\title{
Five new species and one new record of Astrothelium (Trypetheliaceae, Ascomycota) from Thailand
}

\section{Theerapat LUANGSUPHABOOL, H. Thorsten LUMBSCH, André APTROOT, Jittra PIAPUKIEW and Ek SANGVICHIEN}

\begin{abstract}
Five new species and one new record of Astrothelium (Trypetheliaceae) are reported from Thailand. Phylogenetic analysis of four DNA loci (ITS, nuLSU, mtSSU rDNA and RPB1) demonstrated the placement of the new species within Astrothelium, as well as their distinction from similar or related taxa. The new species are: A. flavocoronatum, with a yellow pigment surrounding the ostiole, and 3-septate ascospores $22-28 \times 8.0-9.5 \mu \mathrm{m} ; A$. macrostiolatum, with large whitish ostiolar area, a hamathecium inspersed with small oil droplets, and 9-11-septate ascospores $80-100 \times 17-19 \mu \mathrm{m} ; A$. neglectum, with lichexanthone on the thallus and pseudostromata, a non-inspersed hamathecium and 3-5-septate ascospores 21-25 $\times 7.5-9.5 \mu \mathrm{m} ; A$. neovariolosum, with inspersed hamathecium and 3-septate ascospores 17-23 $\times 6-7 \mu \mathrm{m}$; and $A$. siamense, with inspersed hamathecium and 4-7-septate ascospores 30-50 $\times 10.5-12.0 \mu \mathrm{m}$. Astrothelium aenascens is reported from Thailand for the first time.
\end{abstract}

Key words: lichen-forming fungi, phylogeny, taxonomy, tropical lichens, Trypetheliales

Accepted for publication 6 fune 2016

\section{Introduction}

The genus Astrothelium Eschw. includes pyrenocarpous lichen-forming fungi within Trypetheliaceae (Harris 1984, 1995). Originally restricted to species with lateral, fused ostioles and transversely septate ascospores, in its revised delineation it comprises the majority of species in the Trypetheliaceae (Aptroot \& Lücking 2016), with variable ascoma arrangement and ascospore septation. In both its traditional and its current circumscription, the genus has a pantropical

T. Luangsuphabool: Program in Biotechnology, Faculty of Science, Chulalongkorn University, Pathumwan, Bangkok, 10330 Thailand.

H. T. Lumbsch: Science and Education, The Field Museum, 1400 S. Lake Shore Drive, Chicago, Illinois 60605, USA.

A. Aptroot: ABL Herbarium, Gerrit van der Veenstraat 107, NL-3762 XK Soest, The Netherlands.

J. Piapukiew: Department of Botany, Faculty of Science, Chulalongkorn University, Pathumwan, Bangkok, 10330 Thailand.

E. Sangvichien (corresponding author): Department of Biology, Faculty of Science, Ramkhamhaeng University, Bangkapi, Bangkok, 10240 Thailand. Email: eks@ru.ac.th distribution (Harris 1984; Makhija \& Patwardhan 1989; Awasthi 1991; Aptroot et al. 2008; Kirk et al. 2008; Aptroot 2009; Hyde et al. 2013).

Studies on species diversity in taxa with astrothelioid ascomata and ascospores in Astrothelium (i.e. Astrothelium in its previous sense) have focused mostly on neotropical regions (Malme 1924; Harris 1984; 1995; Aptroot et al. 2008; Lücking et al. 2011; Lima et al. 2013; Córdova-Chávez et al. 2014). In contrast, the diversity of this group in the Indomalayan area is far less known, with the exception of the Indian subcontinent (Makhija \& Patwardhan 1988, 1989; Awasthi 2000; Singh \& Sinha 2010; Weerakoon \& Aptroot 2014). Some of the species within this group found in the Indian subcontinent are believed to be endemic to the area (Makhija \& Patwardhan 1989; Weerakoon \& Aptroot 2014). The diversity of Astrothelium species with astrothelioid ascomata and ascospores in Thailand is poorly known, with only four species recorded: $A$. cinnamomeum (Eschw.) Müll. Arg., A. eustomum (Mont.) Müll. Arg., A. galbineum Kremp., and 
A. variolosum (Ach.) Müll. Arg. (Vongshewarat 2000; Aptroot et al. 2007). These taxa are either widely distributed in South-East Asia or are pantropical (Aptroot et al. 2008).

The aim of this study was to investigate the diversity of astrothelioid species of Astrothelium in Thailand, including taxonomy, chemistry and molecular data. We found the diversity to be higher than previously understood, with five species described here new to science and one new record for Thailand.

\section{Material and Methods}

\section{Specimen collection, identification and mycobiont isolation}

Specimens were collected from tropical rainforest and submontane evergreen forests in several locations in Thailand (Table 1). Cross-sections were mounted in tap water and investigated using an Olympus SZ11 stereomicroscope and Olympus BX41 compound microscope with differential interference contrast (DIC) (Olympus U-DICT), connected to a Canon EOS650 digital camera. Secondary metabolites were examined by colour spot test $(10 \% \mathrm{KOH}$, saturated solution $\mathrm{NaClO}$ and $p$ phenylenediamine dissolved in ethanol), reaction under long-wave UV light $(360 \mathrm{~nm})$, and thin-layer chromatography (TLC) using solvent A (Culberson 1972; Lumbsch 2002).

The lichen mycobionts were isolated from fresh material by the ascospore discharge technique (Sangvichien et al. 2011). Ascospore germination and cultivation of the mycobiont was carried out on Malt-Yeast Extract medium incubated at room temperature $\left(32-35{ }^{\circ} \mathrm{C}\right)$. Fifteen mycobionts developed colonies after 4-6 weeks that were used in this study. Lichen specimens and mycobiont cultures were deposited at the Lichen Herbarium of Ramkhamhaeng University (RAMK), Bangkok.

\section{DNA extraction and PCR amplification}

Fragments of mycobiont cultures were used for genomic DNA extraction using the CTAB method as modified by Cubero \& Crespo (2002). DNA amplification was performed for four nucleotide markers: 1) internal transcribed spacer (ITS), 2) nuclear large subunit ribosomal DNA (nuLSU), 3) mitochondrial small subunit ribosomal DNA (mtSSU), and 4) the largest subunit of RNA polymerase II (RPB1) using the following primers: 1) ITS1F (Gardes \& Bruns 1993) with ITS4 (White et al. 1990), 2) LR0R with LR3 (Vilgalys \& Hester 1990), 3) mrSSU1 (Zoller et al. 1999) with MSU7 (Zhou \& Stanosz 2001), and 4) RPB1-Af with RPB1-Cr (Matheny et al. 2002).
The $50 \mu \mathrm{l}$ PCR reaction consisted of $5 \mu \mathrm{l} 10 \times$ $P f u$ Buffer with $\mathrm{MgSO}_{4}, 2 \mathrm{mM}$ of dNTP mix, $20 \mu \mathrm{M}$ of each primer, $1.25 \mathrm{U}$ of $P f u$ DNA Polymerase (Thermo Fisher Scientific Inc.) and $5 \mu \mathrm{l}$ of $1 / 10$ dilution of DNA solution. PCR conditions were as follows: initial denaturation for $1 \mathrm{~min}$ at $94^{\circ} \mathrm{C}$ and 38 cycles of $94^{\circ} \mathrm{C}$ for $1 \mathrm{~min}, 51^{\circ} \mathrm{C}$ for $1 \mathrm{~min}$ (ITS1F/ITS4), $52^{\circ} \mathrm{C}$ for $45 \mathrm{~s}$ (LR0R/LR3), $53^{\circ} \mathrm{C}$ for $45 \mathrm{~s}$ (mrSSU1/MSU7) and $52^{\circ} \mathrm{C}$ for $1.30 \mathrm{~min}$ (RPB1-Af/RPB1-Cr), followed by an extension at $72^{\circ} \mathrm{C}$ for $1 \mathrm{~min}$, and a final extension at $72^{\circ} \mathrm{C}$ for $5 \mathrm{~min}$. The samples were detected under UV light using agarose gel electrophoresis containing DNA Stain G (SERVA). The Gel/PCR DNA Fragments Extraction Kit (Genaid, Taiwan) was used to clean up the PCR products, according to the manufacturer's instructions, and DNA was sequenced at 1st BASE Laboratories (Malaysia).

\section{Sequence alignments and phylogenetic analyses}

DNA sequences were aligned using MUSCLE (Edgar 2004) and manually adjusted using MEGA v.6 software (Tamura et al. 2013). Two samples of Bathelium madreporiforme were selected as outgroup. Single locus analyses (data not shown) did not show conflict, hence a concatenated dataset from our loci was used (Table 1). The nucleotide substitution model was determined using jModelTest v.2.1.4 (Darriba et al. 2012) with the Akaike Information Criterion (AIC). The GTR $+\mathrm{I}+\mathrm{G}$ model was chosen for phylogenetic tree reconstruction through maximum likelihood (ML) and Bayesian inference (BI). Maximum likelihood analyses were carried out using RAxML-HPC2 v.8.2.4 (Stamatakis et al. 2008) on the Cipres Web Portal (https://www.phylo.org) and bootstrap values were calculated with 1000 pseudoreplicates. Bayesian analysis was performed using MrBayes v.3.2.1 (Ronquist \& Huelsenbeck 2003) for 10 million generations with two independent runs of four chains. Tree samples were saved every 100th trees and the mean standard deviation of split frequencies $<0.01$. Additionally, maximum parsimony (MP) trees were estimated using PAUP $^{\star}$ v.4.0b10 (Swofford 1999) with a heuristic search algorithm and bootstrap values were calculated using 1000 replicates. Phylogenetic trees were visualized using FigTree v.1.4.2 (http:// tree.bio.ed.ac.uk/software/figtree/).

\section{Results and Discussion}

Seventy-two new DNA sequences from our loci (ITS, nuLSU, mtSSU, RPB1) were generated for this study (Table 1). The concatenated dataset had 3138 nucleotide positions. Molecular data supported the presence of 17 lineages of Astrothelium (Fig. 1), including five new species (A. flavocoronatum, A. macrostiolatum, $A$. neglectum, $A$. neovariolosum and $A$. siamense) and a new record from Thailand (see Taxonomic Treatment). 
TABLE 1. Species and specimens used in this study, with vouchers, location, herbarium (RAMK) and GenBank Accession numbers. Newly generated sequences are in bold. ${ }^{\star}=$ sequences from lichen thalli.

\begin{tabular}{|c|c|c|c|c|c|}
\hline \multirow[b]{2}{*}{ Taxon } & \multirow[b]{2}{*}{ Voucher information } & \multicolumn{4}{|c|}{ GenBank Accession numbers } \\
\hline & & ITS & nuLSU & $\mathrm{mtSSU}$ & $R P B 1$ \\
\hline Astrothelium aenascens HRK93 & Thailand, Phitsanulok, 027887 (RAMK) & LC127385 & LC127403 & LC128018 & LC128036 \\
\hline A. aenascens HRK98 & Thailand, Phitsanulok, 027888 (RAMK) & LC127386 & LC127404 & LC128019 & LC128037 \\
\hline A. cinnamomeum DUKE & Costa Rica, Lücking 15322b (F) & DQ782839 & AY584652 & AY584632 & DQ782824 \\
\hline A. crassum MPN98 & Peru, Nelsen 4004a (F) & - & GU327710 & GU327685 & - \\
\hline A. crassum MPN335 & Brazil, Cáceres $6011(\mathrm{~F})$ & - & KM453761 & KM453827 & - \\
\hline A. flavocoronatum KY859 & Thailand, Nakhon Nayok, 027890 (RAMK) & LC127381 & LC127398 & LC128014 & LC128030 \\
\hline A. flavocoronatum TSL63 & Thailand, Phetchabun, 027889 (RAMK) & AB758900 & LC127397 & AB759874 & LC128031 \\
\hline A. laevigatum MPN43 & Peru, Nelsen s. n. (F) & - & KM453768 & KM453833 & - \\
\hline A. leucoconicum MPN42 & Peru, Nelsen 4000c (F) & - & KM453764 & KM453830 & - \\
\hline A. leucosessile MPN258 & Panama, Lücking 27059 (F) & - & KM453762 & KM453828 & - \\
\hline A. macrocarpum MPN260 & Panama, Lücking 27077 (F) & - & KM453763 & KM453829 & - \\
\hline A. macrocarpum NSR6 & Thailand, Nakhon Si Thammarat, 027891 (RAMK) & AB759880 & LC127402 & AB759879 & LC128033 \\
\hline A. macrocarpum UBN37 & Thailand, Ubon Ratchathani, 027892 (RAMK) & LC127384 & LC127400 & LC128015 & LC128032 \\
\hline A. macrocarpum UBN43 & Thailand, Ubon Ratchathani, 027894 (RAMK) & LC127383 & LC127399 & LC128016 & LC128034 \\
\hline A. macrocarpum UBN113 & Thailand, Ubon Ratchathani, 027893 (RAMK) & LC127382 & LC127401 & LC128017 & LC128035 \\
\hline A. macrostiolatum $\mathrm{PHL} 84^{\star}$ & Thailand, Loei, 027895 (RAMK) & LC127389 & LC127407 & LC128022 & LC128040 \\
\hline A. neglectum TAK8 & Thailand, Tak, 027898 (RAMK) & LC127392 & LC127410 & LC128025 & LC128043 \\
\hline A. neglectum TAK 12 & Thailand, Tak, 027896 (RAMK) & LC127393 & LC127411 & LC128026 & LC128044 \\
\hline A. neglectum TAK 17 & Thailand, Tak, 027897 (RAMK) & LC127394 & LC127412 & LC128027 & LC128045 \\
\hline A. neovariolosum KY777 & Thailand, Nakhon Nayok, 027899 (RAMK) & LC127390 & LC127408 & LC128023 & LC128041 \\
\hline A. neovariolosum KY848 & Thailand, Nakhon Nayok, 027900 (RAMK) & LC127391 & LC127409 & LC128024 & LC128042 \\
\hline A. obtectumMPN422 & Brazil, Lücking $31242(\mathrm{~F})$ & - & KM453767 & KM453832 & - \\
\hline A. robustum MPN754 & Costa Rica, Mercado-Díaz 586(F) & - & KM453760 & KM453826 & - \\
\hline A. scorioides MPN770 & Fiji, Lumbsch 20556h (F) & - & KM453766 & KM453831 & - \\
\hline A. siamense $\mathrm{KRB} 105$ & Thailand, Krabi, 027901 (RAMK) & LC127387 & LC127405 & LC128020 & LC128038 \\
\hline A. siamense $\mathrm{KRB} 139$ & Thailand, Krabi, 027902 (RAMK) & LC127388 & LC127406 & LC128021 & LC128039 \\
\hline A. versicolor MPN259 & Panama, Lücking 27045 (F) & - & KM453769 & KM453834 & - \\
\hline A. versicolor MPN703 & Brazil, Cáceres \& Aptroot 11137 (F) & - & KM453765 & - & - \\
\hline Bathelium madreporiforme NAN95 & Thailand, Nan, 027903 (RAMK) & LC127396 & LC127414 & LC128029 & LC128047 \\
\hline B. madreporiforme UBN147 & Thailand, Ubon Ratchathani, 027904 (RAMK) & LC127395 & LC127413 & LC128028 & LC128046 \\
\hline
\end{tabular}




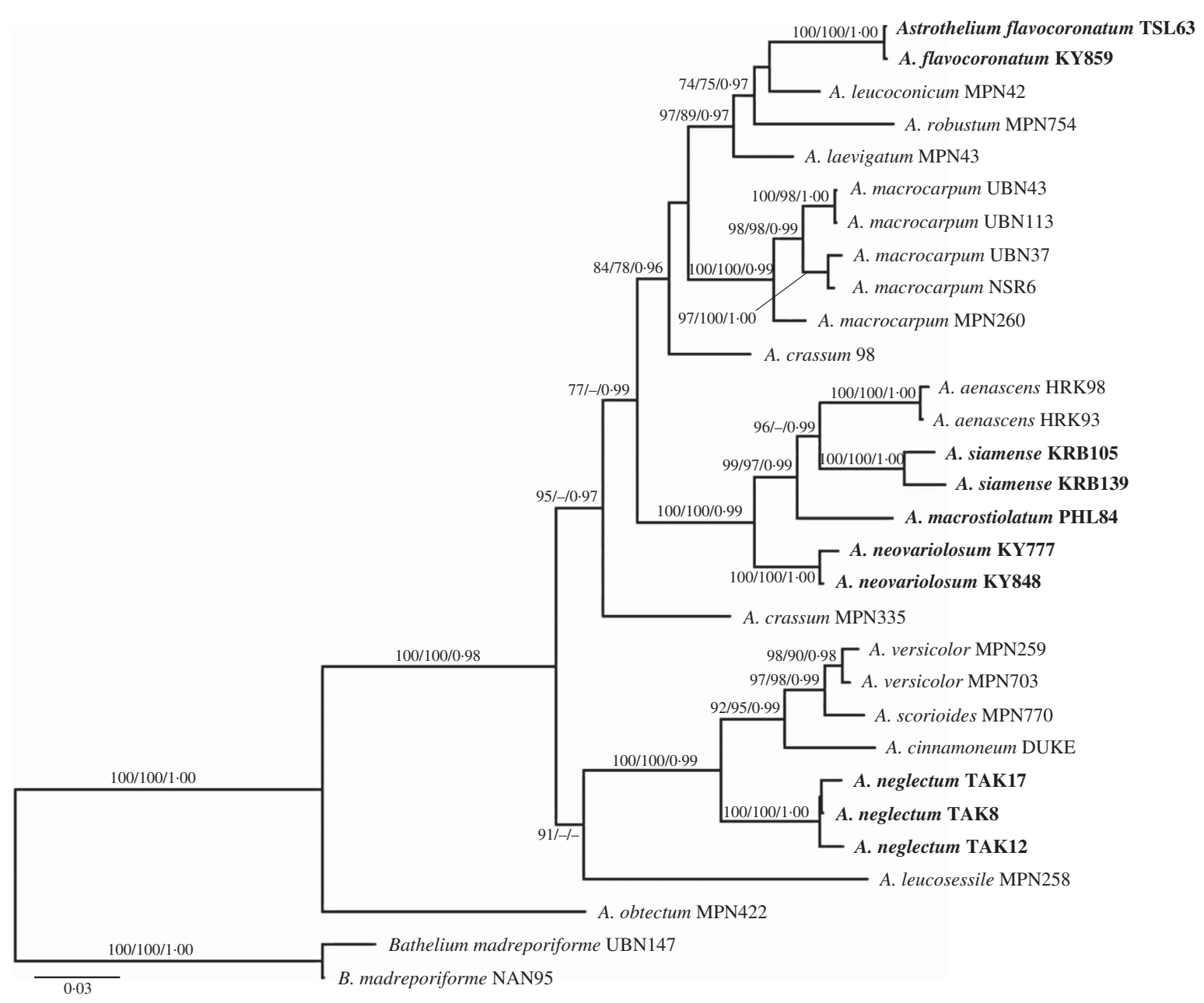

FIG. 1. Phylogenetic relationships of selected astrothelioid species in the genus Astrothelium based on maximum likelihood, maximum parsimony and Bayesian inference analyses using four loci (ITS, nuLSU, mtSSU, RPB1). The most likely tree obtained using RAxML is shown here. ML and MP bootstrap values $\geq 70 \%$ and posterior probabilities $\geq 0.95$ are given at branches in this sequence. 
The new species $A$. macrostiolatum, $A$. neovariolosum and $A$. siamense are closely related and also share certain phenotypic characters, such as a green thallus, white pseudostromata lacking anthraquinones and a hamathecium inspersed with oil droplets. However, they differ in ascospore characters (see below). These three new species form a paraphyletic grade basal to $A$. aenascens Aptroot (Fig. 1), which agrees in the inspersed hamathecium but differs in producing anthraquinones on ascomata. Astrothelium flavocoronatum also differs from the other new species in containing anthraquinones on the ascomata. This new species is similar to $A$. aenascens Aptroot and $A$. macrocarpum (Fée) Aptroot \& Lücking (syn.: $A$. galbineum Kremp.) (Aptroot \& Lücking 2016) in having anthraquinones and 3-septate ascospores of a similar size. However, our molecular data supported the distinction of $A$. flavocoronatum from $A$. aenascens and A. macrocarpum. The molecular data also support that Astrothelium neglectum, a fifth new species, is distinct from $A$. neovariolosum and $A$. siamense, two species that are similar to the new taxon in having a green thallus, white pseudostromata and containing lichexanthone. However, ascospore characters differ between these taxa and the hamathecium lacks oil droplets in the latter two species.

Astrothelium macrocarpum (Fée) Aptroot \& Lücking (syn.: A. galbineum Kremp.) has been reported as the most common Astrothelium species in Thailand (Vongshewarat 2000). Specimens morphologically consistent with that species were also found in this study. However, although specimens from the Neotropics and Thailand form a monophyletic clade, the molecular data suggest that the Thai material is somewhat distinct from the neotropical material (Fig. 1). The circumscription of $A$. macrocarpum (as $A$. galbineum) has been discussed previously. Harris (1984) reduced $A$. ochrothelizum Müll. Arg. to synonymy with $A$. galbineum, while these two species were separated by Makhija \& Patwardhan (1989) based on ascoma characters. In fact, in A. macrocarpum the ascomata are totally embedded in the pseudostromata as in the Thai material (Vongshewarat 2000; Aptroot et al. 2008; Aptroot 2009).

\section{Taxonomic Treatment}

\section{Astrothelium flavocoronatum \\ Luangsuphabool, Aptroot \& Sangvichien. sp. nov.}

MycoBank No.: MB 816951

Similar to Astrothelium diplocarpum in having anthraquinone pigments around the ostiole neck, but differing in having smaller ascospores; thallus yellow to green, perithecial wall carbonized, ostiole with yellow anthraquinone, ascospores 3-septate, $22-28 \times 8.0-9.5 \mu \mathrm{m}$.

Type: Thailand, Nakhon Nayok Province, Khao Yai National Park, montane evergreen forest, on tree bark, $14^{\circ} 26^{\prime} \mathrm{N}, 101^{\circ} 22^{\prime} \mathrm{E}$, alt. $760 \mathrm{~m}, 2015$, Luangsuphabool KY859 (RAMK-027890-holotype).

(Fig. 2A-C)

Thallus crustose, corticate, yellow to green, smooth, continuous, prothallus black; cortex distinct, $40-70 \mu \mathrm{m}$ thick; algal layer continuous, $35-75 \mu \mathrm{m}$ thick; medulla 120-175 $\mu \mathrm{m}$ thick. Algae trentepohlioid.

Ascomata perithecia, pyriform, black, 0.40-0.85 mm diam., semi-immersed to emergent, solitary, usually consisting of two cavities that are joined with a common ostiole. Wall carbonized, $\leq c$. $50 \mu \mathrm{m}$ thick. Ostiole apical, black, surrounded by yellow layer. Pseudostromata raised above the thallus, covered with thallus cortex or naked and carbonized. Hamathecium hyaline, not inspersed; paraphyses anastomosing, 0.85-1.00 $\mu \mathrm{m}$ thick. Asci clavate, $105-110 \times$ $18.5-19.0 \mu \mathrm{m}$. Ascospores 8 per ascus, hyaline, transversely 3 -septate, narrowly ellipsoid, $22-28 \times 8.0-9.5 \mu \mathrm{m}$, lumina diamondshaped to rounded.

Pycnidia not observed.

Chemistry. Thallus UV-, K+ yellow, C-, $\mathrm{KC}-, \mathrm{P}-$. Ascomata: around ostiole $\mathrm{UV}+$ orange, $\mathrm{K}+$ red, $\mathrm{C}+$ red, $\mathrm{P}-$. TLC: parietin, emodin.

Etymology. The specific epithet refers to the yellow tissue which surrounds the ostiole of the new species.

Notes. This new species is similar to the neotropical Astrothelium diplocarpum Nyl. in 

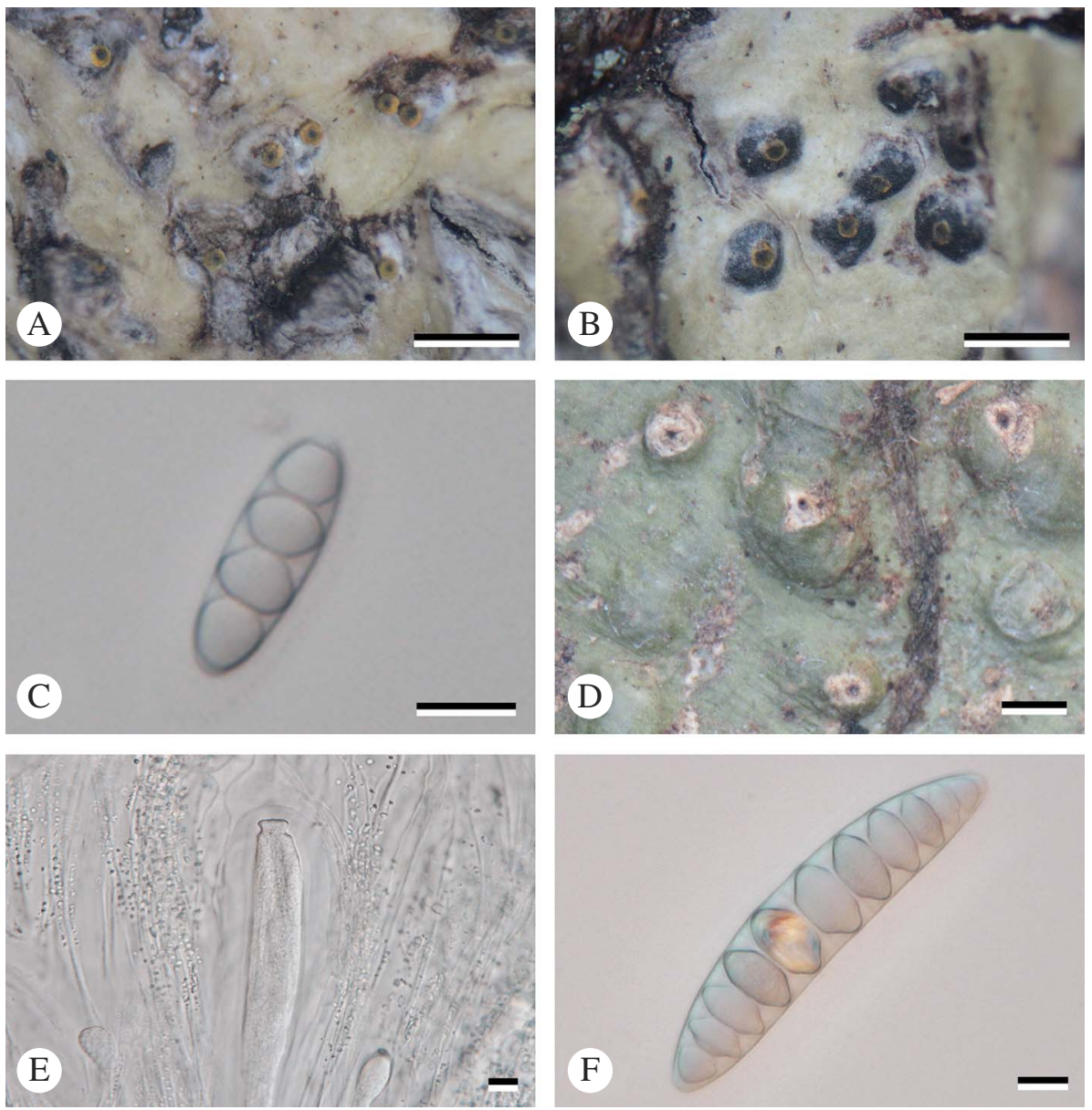

FIG. 2. A-C, Astrothelium flavocoronatum (holotype): A \& B, thallus with ascomata; C, ascospores. D-F, Astrothelium macrostiolatum (holotype): D, thallus with ascomata; E, ascus and hamathecium inspersed; $\mathrm{F}$, ascospores. Scales: A, B \& D = $1 \mathrm{~mm}$; C, E \& F $=10 \mu \mathrm{m}$. In colour online.

having anthraquinone pigments around the ostiole neck, but differs in having smaller ascospores (9-septate, $90-110 \times 22-28 \mu \mathrm{m}$ in A. diplocarpum) (Harris 1995; Aptroot et al. 2008). Also, A. macrocarpum (Fée) Aptroot \& Lücking (syn.: $A$. galbineum Kremp.) and $A$. aenascens Aptroot are similar in having ascomata with anthraquinones and in the ascospore characters, but the new species differs in having ascomata with two locules (several locules with one to several ostioles in $A$. macrocarpum) and a non-inspersed hamathecium (inspersed in $A$. aenascens). Molecular evidence supports this distinction.
Additional specimen examined. Thailand: Phetchabun: Thung Salaeng Luang National Park, montane evergreen forest, on tree bark, $16^{\circ} 35^{\prime} \mathrm{N}, 100^{\circ} 52^{\prime} \mathrm{E}$, alt. $740 \mathrm{~m}$, 2008, Luangsuphabool TSL63 (RAMK-027889).

\section{Astrothelium macrostiolatum Luangsuphabool, Aptroot \& Sangvichien. sp. nov.}

\section{MycoBank No.: MB 816952}

Similar to Astrothelium eustomum in thallus and pseudostroma characters, but differing in having 9-11 septate, $80-100 \times 17-19 \mu \mathrm{m}$ ascospores, an inspersed hamathecium and lacking secondary metabolites; thallus 
olive-green, pseudostroma with whitish ostiolar area, hamathecium inspersed with small oil droplets.

Type: Thailand, Loei Province, Phu Ruea District, Phu Luang Wildlife Sanctuary, montane evergreen forest, on tree bark, $17^{\circ} 16^{\prime} \mathrm{N}, 101^{\circ} 30^{\prime} \mathrm{E}$, alt. $1460 \mathrm{~m}, 2014$, Luangsuphabool PHL84 (RAMK-027895-holotype).

\section{(Fig. 2D-F)}

Thallus crustose, corticate, olive-green, smooth or somewhat warted, shiny, prothallus black; cortex distinct, $15-40 \mu \mathrm{m}$ thick; algal layer continuous, $20-60 \mu \mathrm{m}$ thick, medulla 25-90 $\mu \mathrm{m}$ thick. Alga trentepohlioid.

Ascomata perithecia, pyriform, black, 0.9-1.1 mm diam., common ostiole with two cavities, solitary or immersed in pseudostroma. Wall carbonized, $\leq c .100 \mu \mathrm{m}$ thick. Ostiole apical, black. Pseudostromata white, mostly covered by thallus but leaving a large whitish ostiolar area free. Hamathecium hyaline, inspersed with small oil droplets usually less than $2 \mu \mathrm{m}$ diam.; paraphyses anastomosing, 0.8-1.0 $\mu \mathrm{m}$ thick. Asci clavate, 240-300 $\times 37-55 \mu \mathrm{m}$. Ascospores 8 per ascus, hyaline, transversely 9-11 septate, fusiform, $80-100 \times 17-19 \mu \mathrm{m}$, lumina diamondshaped to rounded.

Pycnidia not observed

Chemistry. Thallus UV-, K+ yellow, C-, $\mathrm{KC}-, \mathrm{P}-$. Pseudostromata UV-, K-, C-, P-. TLC: no substances detected.

Etymology. The specific epithet refers to the large whitish ostiolar area.

Notes. This new species is similar to Astrothelium eustomum (Mont.) Müll. Arg. in thallus and pseudostromatal characters, and also to $A$. diplocarpoides Müll. Arg. and A. diplocarpum $\mathrm{Nyl}$. in having rather large ascospores. However, it differs from those taxa in having more numerous septa, an inspersed hamathecium and a lack of secondary metabolites; 3-5-septate ascospores, a non-inspersed hamathecium, and lichexanthone are found in $A$. eustomum, 5-7-septate ascospores and lichexanthone are characteristic of $A$. diplocarpoides, and 9-septate ascospores, a non-inspersed hamathecium and anthraquinones are found in A. diplocarpum (Harris 1984; Aptroot et al. 2008; Lücking et al. 2011; Aptroot \& Lücking 2016).

\section{Astrothelium neglectum \\ Luangsuphabool, Aptroot \& Sangvichien. sp. nov.}

\author{
MycoBank No.: MB 816953
}

Similar to Astrothelium eustomum in thallus, pseudostroma and ascospore characters, but differing by containing lichexanthone in the thallus; thallus yellow to green, pseudostromata white, hamathecium not inspersed, ascospores 3-5 septate, $21-25 \times 7.5-9.5 \mu \mathrm{m}$.

Type: Thailand, Tak Province, Umphang District, Palatha Village, on tree bark, $15^{\circ} 49^{\prime} \mathrm{N}, 98^{\circ} 50^{\prime} \mathrm{E}$, alt. $500 \mathrm{~m}, 2010$, Luangsuphabool TAK17 (RAMK027897-holotype).

\section{(Fig. 3A-D)}

Thallus crustose, corticate, yellow to green, smooth, shiny, prothallus black; cortex distinct, $65-120 \mu \mathrm{m}$ thick; algal layer continuous, $15-55 \mu \mathrm{m}$ thick, medulla 60 $165 \mu \mathrm{m}$ thick. Alga trentepohlioid.

Ascomata perithecia, pyriform, black, 0.65$1.15 \mathrm{~mm}$ diam., 2-5 cavities with common ostiole immersed in pseudostroma. Wall carbonized, $\leq c .70 \mu \mathrm{m}$ thick. Ostiole apical, black. Pseudostromata white, rounded to irregular, flattened top and raised above the thallus. Hamathecium hyaline, not inspersed; paraphyses anastomosing, $1 \cdot 3-2 \cdot 0 \mu \mathrm{m}$ thick. Asci clavate, $110-140 \times 15-20 \mu \mathrm{m}$. Ascospores 8 per ascus, hyaline, transversely $3-5$ septate,

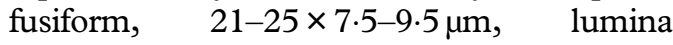
diamond-shaped to rounded.

Pycnidia not observed.

Chemistry. Thallus UV+ yellow (lichexanthone), $\mathrm{K}+$ yellow, $\mathrm{C}-, \mathrm{KC}-, \mathrm{P}-$. Pseudostromata UV+ yellow (lichexanthone), $\mathrm{K}-, \mathrm{C}-, \mathrm{P}-$. TLC: lichexanthone.

Etymology. The specific epithet refers to this species having been previously overlooked.

Notes. The new species is similar to Astrothelium eustomum (Mont.) Müll. Arg. in 

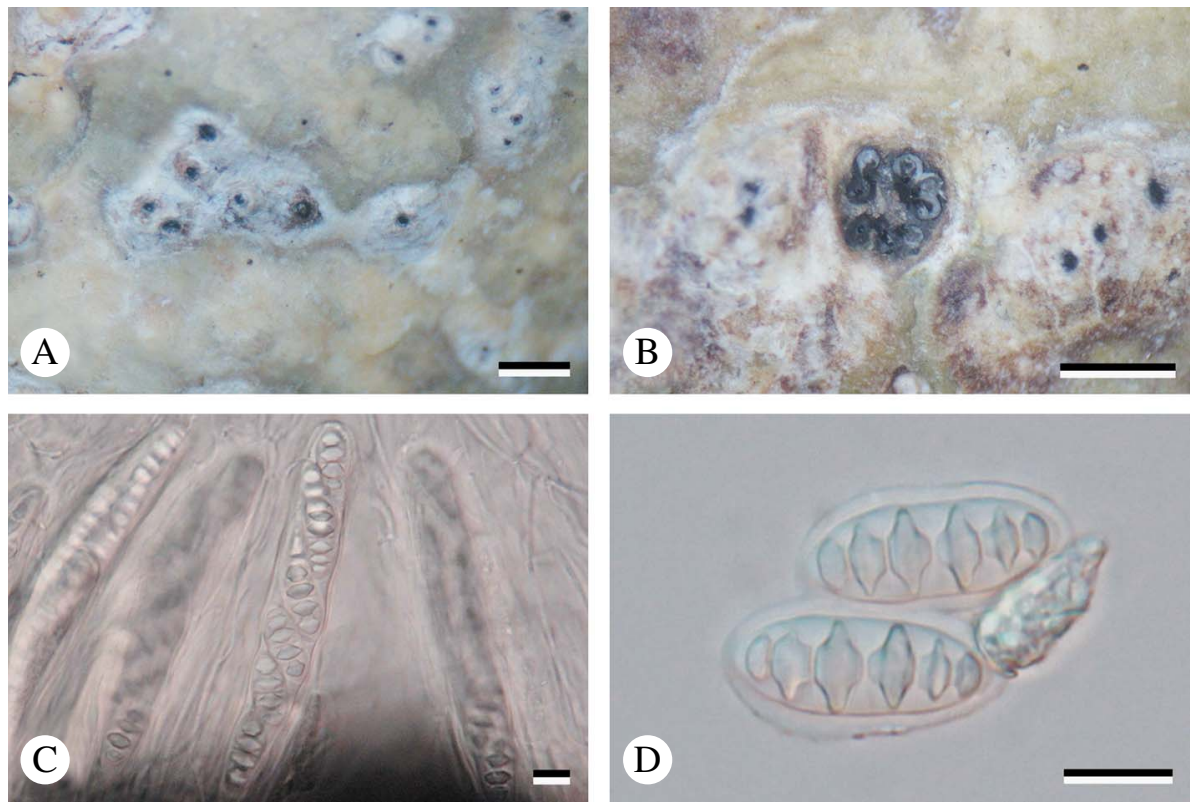

FIG. 3. Astrothelium neglectum (holotype). A, thallus with ascomata; B, ascomata; C, ascus with ascospores; $\mathrm{D}$, mature ascospores. Scales: $\mathrm{A} \& \mathrm{~B}=1 \mathrm{~mm}$; $\mathrm{C} \& \mathrm{D}=10 \mu \mathrm{m}$. In colour online.

thallus, pseudostromatal and ascospore characters, but differs by containing lichexanthone in the thallus, whereas this substance is present only on the ostioles in A. eustomum (Harris 1984; Aptroot et al. 2008; Aptroot 2009). Also, A. neovariolosum and $A$. siamense are similar in having a corticated thallus, white pseudostromata, $\mathrm{KOH}-$ and lichexanthone, but the new species differs in ascospore characters and the non-inspersed hamathecium (3-septate ascospores, $17-23 \times 6-7 \mu \mathrm{m}$, and hamathecium inspersed in $A$. neovariolosum; 4-7-septate, $30-50 \times 10.5-12.0 \mu \mathrm{m}$, and hamathecium inspersed in $A$. siamense).

Additional specimens examined. Thailand: Tak: Umphang District, on tree bark, $15^{\circ} 49^{\prime} \mathrm{N}, 98^{\circ} 50^{\prime} \mathrm{E}$, alt. 500 m, 2010, Luangsuphabool TAK8 (RAMK-027898), TAK12 (RAMK-027896).

\section{Astrothelium neovariolosum Luangsuphabool, Aptroot \& Sangvichien. sp. nov.}

MycoBank No.: MB 816954
Similar to Astrothelium variolosum in pseudostroma and ascospore characters, but differing by an inspersed hamathecium; thallus greenish, pseudostromata grey to yellowish, ascospores 3-septate, 17-23 × 6-7 $\mu \mathrm{m}$.

Type: Thailand, Nakhon Nayok Province, Khao Yai National Park, montane evergreen forest, on tree bark, $14^{\circ} 25^{\prime} \mathrm{N}, 101^{\circ} 22^{\prime} \mathrm{E}$, alt. $750 \mathrm{~m}, 2013$, Luangsuphabool KY777 (RAMK-027899-holotype).

(Fig. 4A-C)

Thallus crustose, corticate, greenish, smooth or somewhat warted, shiny, prothallus black; cortex distinct, $16-28 \mu \mathrm{m}$ thick; algal layer continuous, $18-35 \mu \mathrm{m}$ thick; medulla 40-85 $\mu \mathrm{m}$ thick. Alga trentepohlioid.

Ascomata perithecia, pyriform, black, 0.5$0.8 \mathrm{~mm}$ diam., fused ostiole with two cavities, single to 2-8 aggregate groups immersed in pseudostroma. Wall carbonized, $\leq$ c. $50 \mu \mathrm{m}$ thick. Ostiole apical, black. Pseudostromata grey to yellowish, raised above the thallus, round to irregular. Hamathecium hyaline, inspersed with oil droplets; paraphyses anastomosing, $0.9-1.0 \mu \mathrm{m}$ thick. Asci clavate, $115-125 \times 12.0-13.5 \mu \mathrm{m}$. Ascospores 8 per ascus, hyaline, transversely 

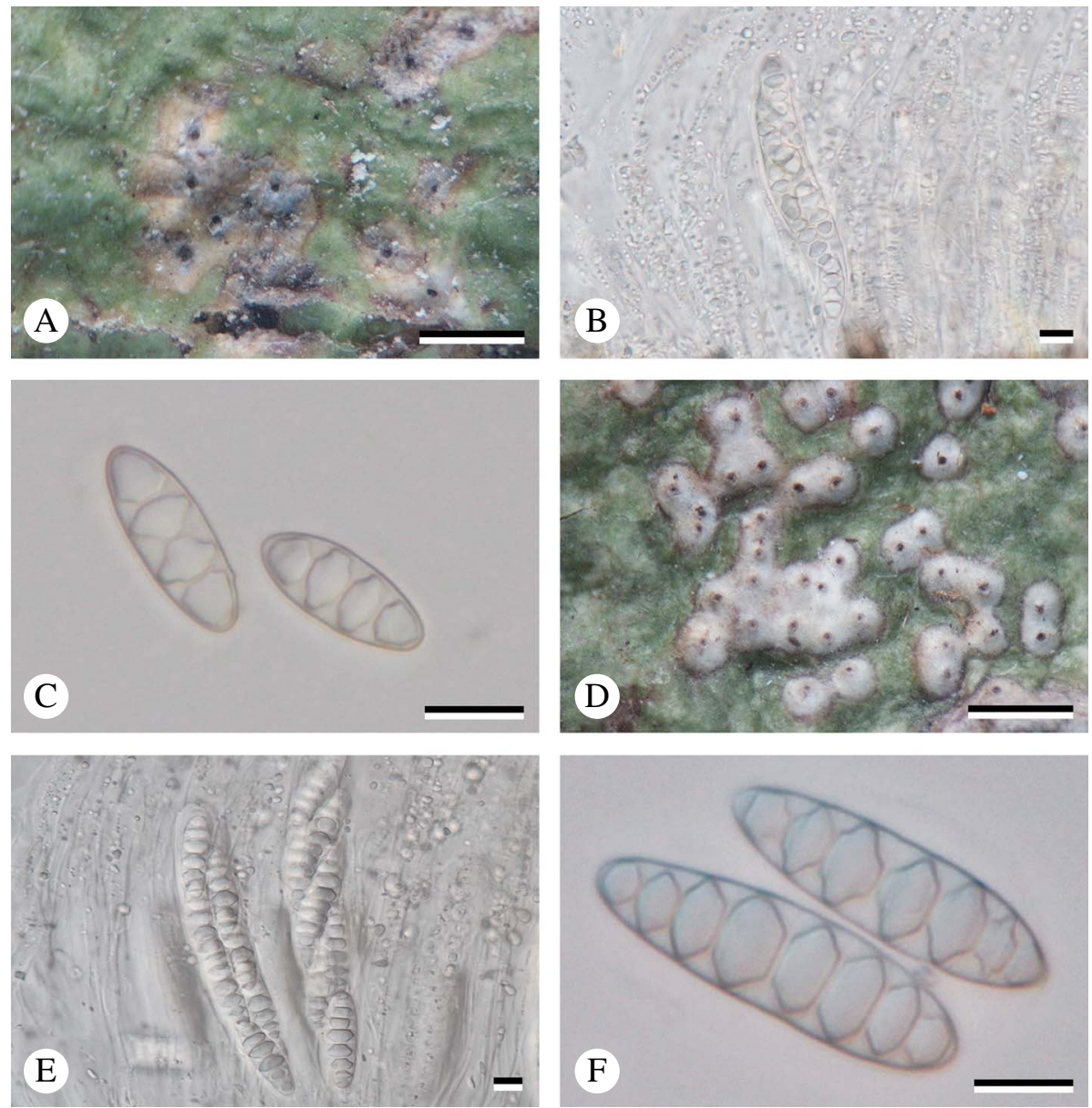

FIG. 4. A-C, Astrothelium neovariolosum (holotype); A, thallus with ascomata; B, ascus with ascospores; C, ascospores. D-F, Astrothelium siamense (holotype); D, thallus with ascomata; E, ascus with ascospores; F, ascospores. Scales: A \& D = $1 \mathrm{~mm} ; \mathrm{B}, \mathrm{C}, \mathrm{E} \& \mathrm{~F}=10 \mu \mathrm{m}$. In colour online.

3-septate, narrowly ellipsoid, 17-23×6$7 \mu \mathrm{m}$, lumina diamond-shaped to rounded.

Pycnidia not observed.

Chemistry. Thallus UV + yellow (lichexanthone), $\mathrm{K}+$ yellow, $\mathrm{C}-$, $\mathrm{KC}-, \mathrm{P}-$. Pseudostromata UV + brown-orange, $\mathrm{K}-$, C-, P-. TLC: lichexanthone.

Etymology. The specific epithet refers to the morphological similarities with $A$. variolosum.

Notes. The new species is most similar to Astrothelium variolosum (Ach.) Müll. Arg. in having white to grey pseudostromata and in ascospore characters, but differs by its inspersed hamathecium (hamathecium not inspersed in $A$. variolosum) (Aptroot et al. 2008; Aptroot 2009).

Additional specimen examined. Thailand: Nakhon Nayok: Khao Yai National Park, tree bark, $14^{\circ} 25^{\prime} \mathrm{N}, 101^{\circ} 22^{\prime} \mathrm{E}$, alt. 760 m, 2014, Luangsuphabool KY848 (RAMK-027900).

\section{Astrothelium siamense \\ Luangsuphabool, Aptroot \& \\ Sangvichien. sp. nov.}

MycoBank No.: MB 816955 
Similar to Astrothelium variolosum in thallus and pseudostroma characters, but differing in having larger ascospores and an inspersed hamathecium; thallus olive-green to yellow, pseudostromata white, hamathecium inspersed, ascospores 4-7 septate, $30-50 \times 10.5-12.0 \mu \mathrm{m}$.

Type: Thailand, Krabi Province, Khlong Thom District, Thung Tieo-Sra Morakot trail, tropical rainforest, on tree bark, $7^{\circ} 55^{\prime} \mathrm{N}, 99^{\circ} 16^{\prime} \mathrm{E}$, alt. $70 \mathrm{~m}, 2012$, Luangsuphabool KRB139 (RAMK-027902-holotype).

\section{(Fig. 4D-F)}

Thallus crustose, corticate, olive-green to yellow, smooth, shiny, prothallus black; cortex distinct, $20-60 \mu \mathrm{m}$ thick; algal layer continuous, $10-40 \mu \mathrm{m}$ thick; medulla 10-40 $\mu \mathrm{m}$ thick. Alga trentepohlioid.

Ascomata perithecia, pyriform, black, 0.26$0.52 \mathrm{~mm}$ diam., common ostiole with two cavities, solitary to aggregated groups immersed in pseudostroma. Wall carbonized, $\leq c .30 \mu \mathrm{m}$ thick. Ostiole apical, black. Pseudostromata white, raised above the thallus, round to irregular. Hamathecium hyaline, inspersed with oil droplets; paraphyses anastomosing, 0.7-1.0 $\mu \mathrm{m}$ thick. Asci clavate, 125-150 $\times 20$ $23 \mu \mathrm{m}$. Ascospores 8 per ascus, hyaline, transversely 4-7 septate, fusiform, 30-50 × 10.5$12.0 \mu \mathrm{m}$, lumina diamond-shaped to rounded.

Pycnidia not observed.

Chemistry. Thallus UV + yellow (lichexanthone), $\mathrm{K}+$ yellow, $\mathrm{C}-, \mathrm{KC}-, \mathrm{P}-$. Pseudostromata UV-, K-, C-, P-. TLC: lichexanthone.

Etymology. The specific epithet refers to 'Siam', the traditional name for Thailand, where the species was collected.

Notes. This new species is similar to Astrothelium variolosum (Ach.) Müll. Arg. in having a green thallus and white to grey pseudostromata, but differs in having larger ascospores and an inspersed hamathecium (3-septate ascospores, 20-26 $\times 7-9 \mu \mathrm{m}$ and hamathecium not inspersed in $A$. variolosum) (Aptroot et al. 2008; Aptroot 2009). The new species is also similar to $A$. neovariolosum in thallus and pseudostroma characters and in containing lichexanthone, but differs in having larger ascospores (3-septate, 17-23 × 6-7 $\mu \mathrm{m}$ in $A$. neovariolosum).
Additional specimen examined. Thailand: Krabi: Khlong Thom District, Hin Phoeng Waterfall, on tree bark, $7^{\circ} 51^{\prime} \mathrm{N}, 99^{\circ} 15^{\prime} \mathrm{E}$, alt. $75 \mathrm{~m}, 2012$, Luangsuphabool KRB105 (RAMK-027901).

\section{New record for Thailand}

\section{Astrothelium aenascens Aptroot}

Lichenologist 48: xx (2016).

Thallus crustose, corticated, greenish to grey, smooth. Alga trentepohlioid.

Ascomata perithecia, black, carbonized, aggregated groups immersed in pseudostroma and sharing common ostiole. Ostiole apical, black. Pseudostromata raised, containing yellow to orange pigment. Hamathecium hyaline, inspersed with oil droplets, branched and anastomosing. Ascospores 8 per ascus, transversely 3-septate, $24-30 \times 9-10 \mu \mathrm{m}$, lumina diamond-shaped to rounded.

Chemistry. Thallus UV+ yellow to orange, $\mathrm{K}+$ yellow. Pseudostromata UV+ red-orange, $\mathrm{K}+$ red. TLC: lichexanthone, parietin.

Specimens examined. Thailand: Phitsanulok Province: Nakhon Thai District, Phu Hin Rong Kla National Park, montane evergreen forest, on tree bark, $16^{\circ} 59^{\prime} \mathrm{N}$, $100^{\circ} 59^{\prime} \mathrm{E}$, alt. $1310 \mathrm{~m}, 2009$, Luangsuphabool HRK93 (RAMK-027887), HRK98 (RAMK-027888).

This study was financially supported by the Royal Thai Government through Ramkhamhaeng University, a CU Graduate School Thesis Grant and a scholarship from the Human Resource Development in Science Project (Science Achievement Scholarship of Thailand). We would like to thank Kansri Boonpragob and Kajonsak Vongshewarat for their helpful suggestions and Anupan Kongbangkerd and Thanakorn Wongsa for their assistance during fieldwork.

\section{REFERENCES}

Aptroot, A. (2009) Trypetheliaceae. Flora of Australia 57: 535-552.

Aptroot, A. \& Lücking, R. (2016) A revisionary synopsis of the Trypetheliaceae (Ascomycota: Trypetheliales). Lichenologist 48: 763-982.

Aptroot, A., Saipunkaew, W., Sipman, H. J. M., Sparrius, L. B. \& Wolseley, P. A. (2007) New lichens from Thailand, mainly microlichens from Chiang Mai. Fungal Diversity 24: 75-134.

Aptroot, A., Lücking, R., Sipman, H. J. M., Umaña, L. \& Chaves, J. L. (2008) Pyrenocarpous lichens with 
bitunicate asci. A first assessment of the lichen biodiversity inventory in Costa Rica. Bibliotheca Lichenologica 97: 1-162.

Awasthi, D. D. (1991) A key to the microlichens of India, Nepal and Sri Lanka. Bibliotheca Lichenologica 40: $1-340$.

Awasthi, D. D. (2000) Lichenology in Indian Subcontinent: A Supplement to 'A Handbook of Lichens'. Dehra Dun: Bishen Singh Mahendra Pal Singh.

Córdova-Chávez, O., Aptroot, A., Castillo-Camposa, G., Cáceres, M. E. S. \& Pérez-Pérez, R. E. (2014) Three new lichen species from cloud forest in Veracruz, Mexico. Cryptogamie, Mycologie 35: 157-162.

Cubero, O. F. \& Crespo, A. (2002) Isolation of nucleic acids from lichens. In Protocols in Lichenology. Culturing, Biochemistry, Ecophysiology and Use in Biomonitoring (I. Kranner, R. P. Beckett \& A. K. Varma, eds): 381-392. Berlin: Springer.

Culberson, C. F. (1972) Improved conditions and new data for the identification of lichen products by a standardized thin-layer chromatographic method. fournal of Chromatography 72: 113-125.

Darriba, D., Taboada, G. L., Doallo, R. \& Posada, D. (2012) jModelTest 2: more models, new heuristics and parallel computing. Nature Methods 9: 772 .

Edgar, R. C. (2004) MUSCLE: multiple sequence alignment with high accuracy and high throughput. Nucleic Acids Research 32: 1792-1797.

Gardes, M. \& Bruns, T. D. (1993) ITS primers with enhanced specificity for basidiomycetes - application to the identification of mycorrhizae and rusts. Molecular Ecology 2: 113-118.

Harris, R. C. (1984) The family Trypetheliaceae (Loculoascomycetes: lichenized Melanommatales) in Amazonian Brazil. Supplement Acta Amazonica 14: $55-80$.

Harris, R. C. (1995) More Florida Lichens. Including the 106 Tour of the Pyrenolichens. Bronx, New York: Published by the author.

Hyde, K. D., Liu, J. K., Binder, M., Aryawansha, H., Boehm, E., Boonmee, S., Braun, U., Chomnunti, P., Crous, P. W., Dai, D. et al. (2013) Families of Dothideomycetes. Fungal Diversity 63: 1-313.

Kirk, P. M., Cannon, P. F., Minter, D. W. \& Stalpers, J. A. (2008) Dictionary of the Fungi. 10th edn. Wallingford: CAB International.

Lima, E. L., Maia, L. C., Aptroot, A. \& Cáceres, M. E. S. (2013) New lichen species from Vale do Catimbau, Pernambuco, Brazil. Bryologist 116: 327-329.

Lücking, R., Seavey, F., Common, R. S., Beeching, S. Q., Breuss, O., Buck, W. R., Crane, L., Hodges, M., Hodkinson, B. P., Lay, E. et al. (2011) The lichens of Fakahatchee Strand Preserve State Park, Florida: proceedings from the 18th Tuckerman Workshop. Bulletin of the Florida Museum of Natural History 49: 127-186.

Lumbsch, H. T. (2002) Analysis of phenolic products in lichens for identification and taxonomy. In Protocols in Lichenology. Culturing, Biochemistry, Ecophysiology and Use in Biomonitoring (I. Kranner, R. P. Beckett \& A. K. Varma, eds): 281-295. Berlin: Springer.
Makhija, U. \& Patwardhan, P. G. (1988) Materials for a lichen flora of the Andaman Islands - IV. Pyrenocarpous lichens. Mycotaxon 31: 467-481.

Makhija, U. \& Patwardhan, P. G. (1989) The lichen family Asterotheliaceae sensu Zahlbrucker in India. Biovigyanam 15: 61-89.

Malme, G. O. A. (1924) Die Flechten der ersten Regnellschen Expedition. Astrotheliaceae, Paratheliaceae und Trypetheliaceae. Arkiv før Botanik 19 (1): $1-34$.

Matheny, P. B., Liu, Y. J., Ammirati, J. F. \& Hall, B. D. (2002) Using RPB1 sequences to improve phylogenetic inference among mushrooms (Inocybe, Agaricales). American fournal of Botany 89: 688-698.

Ronquist, F. \& Huelsenbeck, J. P. (2003) MrBayes 3: Bayesian phylogenetic inference under mixed models. Bioinformatics 19: 1572-1574.

Sangvichien, E., Hawksworth, D. L. \& Whalley, A. J. S. (2011) Ascospore discharge, germination and culture of fungal partners of tropical lichens, including the use of a novel culture technique. IMA Fungus 2: 143-153.

Singh, K. P. \& Sinha, G. P. (2010) Indian Lichens: An Annotated Checklist. Kolkata: Botanical Survey of India, Ministry of Environment and Forests.

Stamatakis, A., Hoover, P. \& Rougemont, J. (2008) A rapid bootstrap algorithm for the RAxML web servers. Systematic Biology 57: 758-771.

Swofford, D. L. (1999) PAUP*: Phylogenetic Analysis Using Parsimony (*and Other Methods) Version 4.0b10. Sunderland, Massachusetts: Sinauer Associates.

Tamura, K., Stecher, G., Peterson, D., Filipski, A. \& Kumar, S. (2013) MEGA6: Molecular Evolutionary Genetics Analysis version 6.0. Molecular Biology and Evolution 30: 2725-2729.

Vilgalys, R. \& Hester, M. (1990) Rapid genetic identification and mapping of enzymatically amplified ribosomal DNA from several Cryptococcus species. Fournal of Bacteriology 172: 4239-4246.

Vongshewarat, K. (2000) Study on taxonomy and ecology of the lichen family Trypetheliaceae in Thailand. M.Sc. thesis, Ramkhamhaeng University.

Weerakoon, G. \& Aptroot, A. (2014) Over 200 new lichen records from Sri Lanka, with three new species to science. Cryptogamie, Mycologie 35: $51-62$.

White, T. J., Bruns, T. D., Lee, S. B. \& Taylor, J. W. (1990) Amplification and direct sequencing of fungal ribosomal RNA genes for phylogenetics. In PCR Protocols: A Guide to Methods and Applications (M. A. Innis, D. H. Gelfand, J. J. Sninsky \& T. J. White, eds): 315-322. San Diego: Academic Press.

Zhou, S. \& Stanosz, G. R. (2001) Primers for amplification of mt SSU rDNA, and a phylogenetic study of Botryosphaeria and associated anamorphic fungi. Mycological Research 105: 1033-1044.

Zoller, S., Scheidegger, C. \& Sperisen, C. (1999) PCR primers for the amplification of mitochondrial small subunit ribosomal DNA of lichen-forming ascomycetes. Lichenologist 31: 511-516. 